\title{
A Structural Equation Model of Feasibility Evaluation and Project Success for Public-Private Partnerships in Hong Kong
}

\author{
S. Thomas Ng, Yoki M. W. Wong, and James M. W. Wong
}

\begin{abstract}
A successful public-private partnership (PPP) scheme can be described as one that can lead to the delivery of high-quality end products and/or services, which can satisfy the needs of the community, achieve the intended targets/goals of the government, as well as provide a favorable financial return for the private sector involved with the project. This study aims to establish an evaluation framework for the initial feasibility evaluation of a PPP project that would satisfy all the stakeholders. The factors for evaluating the feasibility of PPP projects can be classified into five broad categories: technical; financial and economic; social; political and legal; and others. Through the structural equation modeling approach, data attained from a questionnaire survey conducted in Hong Kong was analyzed and a model was developed to examine the relationships between different evaluation factors and the overall satisfaction of stakeholders. The results indicate that technical and social aspects are critical to the feasibility of PPP projects, and therefore, are the determining factors for success. This paper should assist relevant stakeholders to improve their understanding on the relative importance of the evaluation factors, and help to establish a comprehensive framework for decision makers to evaluate the feasibility of PPP projects. The predictors for PPP project success were also determined to enrich the knowledge base and help formulate management strategies to better implement the PPP project delivery approach.
\end{abstract}

Index Terms-Critical success factors (CSFs), public-private partnerships (PPP), structural equation modeling (SEM).

\section{INTRODUCTION}

D ELIVERING essential public facilities and services under a limited budget is a major challenge for many governments around the world. A popular solution to confront this challenge is to strategically engage private investors [26], so that fresh ideas, best practices, and the required funding can be brought forth to make these schemes possible [33]. Publicprivate partnerships (PPP) or private finance initiatives (PFI) have been applied to electricity generation projects [4], [79], [81], [89], thermal-electricity power plants [5], natural gas facilities [82], combined-cycle plants [19], power supply control systems [65], information and communications technology

Manuscript received June 4, 2008; revised December 12, 2008, April 27, 2009, August 4, 2009, and October 1, 2009. First published February 1, 2009; current version published April 21, 2010. This work was supported by the Research Grants Council of the Government of Hong Kong Special Administrative for the financial support through the Public Policy Research Scheme under Grant 7010-PPR-4. Review of this manuscript was arranged by Department Editor J. K. Pinto.

The authors are with the Department of Civil Engineering, The University of Hong Kong, Hong Kong (e-mail: tstng@hkucc.hku.hk; h0009282@ hkusua.hku.hk; jmwwong@ @kucc.hku.hk).

Digital Object Identifier 10.1109/TEM.2009.2037142 schemes [22], [24], [53], [80], traffic control centers [62], electrical projects [6], and container terminals [49]. The trend of commitments toward investing in PPP schemes in the energy, telecommunications, water and sewage, and transport sectors around the world over the past two decades is shown in Fig. 1.

As the duties of electrical and electronic engineers continue to expand to other managerial aspects [60], there are no shortages of engineers taking on strategic planning and managing roles in energy and telecommunication projects, in addition to their involvement in investment appraisal, funding arrangement, and asset management decisions [28]. When planning for PPP schemes, engineers shall not lose sight on the external factors, such as government policies, social expectations, and political environments [34], [73], as they could have profound implications on project success. Addressing the concerns of various stakeholders and attempting to produce a synergy effect among various parties has become a great challenge for today's engineers as they try to balance their technical, interdisciplinary, and integrative business roles in a PPP scheme (cf., [54] and [58]).

Although PPP can offer a wide range of benefits viz., better service quality, higher cost efficiency, and greater flexibility, it is not a panacea to every project [39]. The proposer should ensure that a PPP scheme is feasible at the outset, and this is particularly essential when the project is of a sizeable scale and/or when it is socially and politically sensitive. Feasibility studies are effective means to help government officials to determine whether or not a PPP scheme is financially attractive and offers good value-for-money during the early planning stages. Specific targets related to public accountability, business achievements, social concerns, etc. can be identified and built into the feasibility study, along with other critical success factors (CSF's) for the project. This would also help satisfy the diverse interests of the government, private investor and community, and result in a genuinely feasible and mutually beneficial PPP scheme.

In this study, a comprehensive framework for evaluating the initial feasibility of PPP projects is derived by taking into account the success factors and concerns of stakeholders. The paper begins by reviewing the models and factors for evaluating the feasibility of PPP projects and the ways in which success is measured for this type of schemes. It is followed by an introduction of the research method and modeling technique adopted in this research. The framework derived from the structural equation modeling (SEM) approach is then presented with the validation outcomes reported. The paper concludes by discussing the implications of the research findings. 


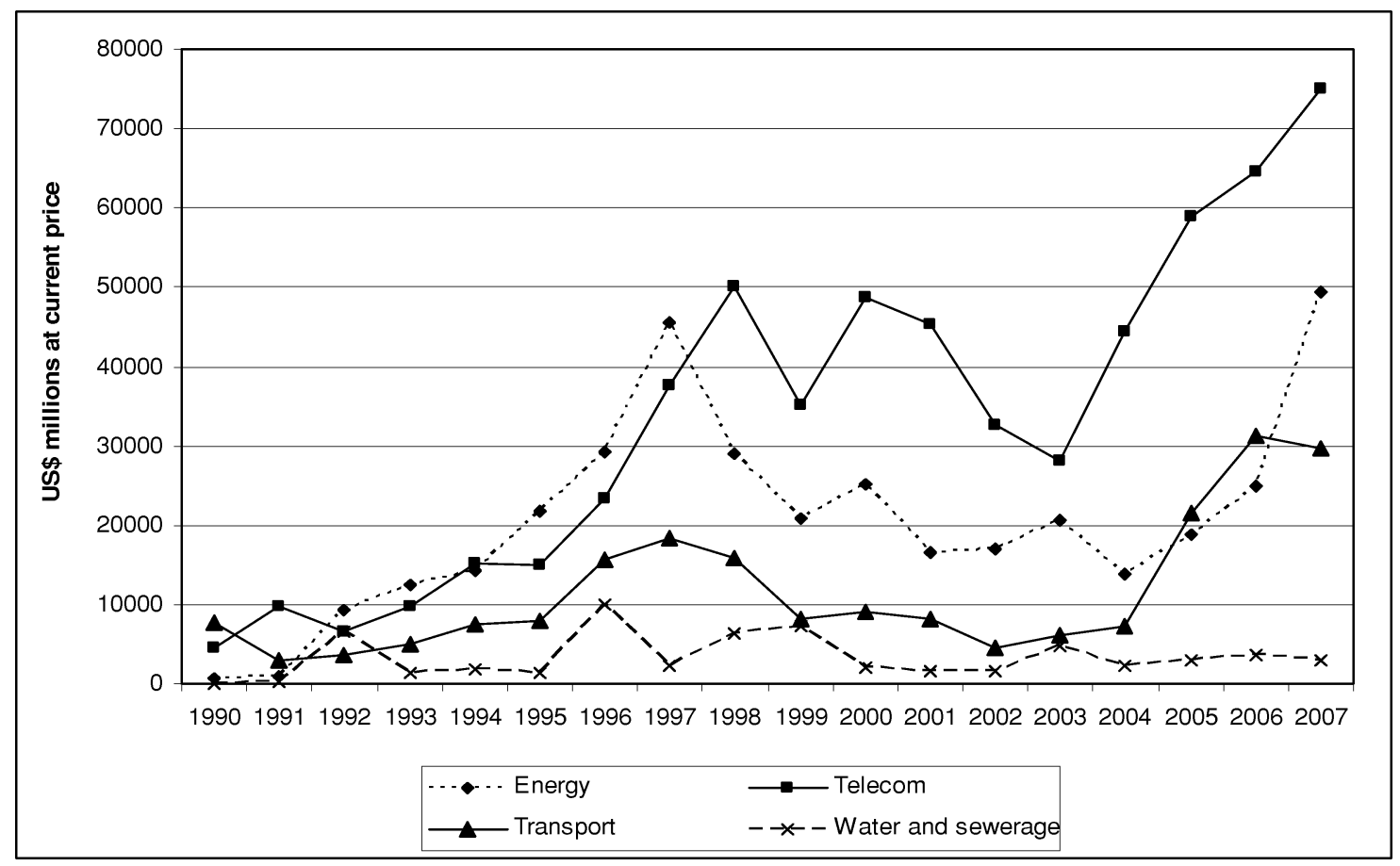

Fig. 1. Global investment commitments in PPP projects (1990-2007). Source: World Bank and public private infrastructure advisory facility, private participation in infrastructure project database. (http://ppi.worldbank.org).

\section{LiteratURE ON PPP FEASIBILITY EVALUATION}

\section{A. Evaluation Models}

Ho and Liu [41] stressed the importance of demonstrating financial viability of a PPP scheme when the initial feasibility study is conducted, as investors will not be interested in committing to a project without a strong business case. Hence, various analytical techniques including the "build-operate-transfer" option valuation model [41], net present value-at-risk method [85], return on equity, debt/cover ratio, cash-flow analysis [77], etc. have been proposed for assessing the financial attractiveness of PPP projects. In practice, the public sector comparator (PSC) is still the most common mechanism for establishing a case of whether or not the PPP approach should be pursued, as the government can justify if a PPP scheme can provide value-for-money over the traditional form of project delivery [1].

Since PSC is governed by the risks-adjusted total cost, less attention has been directed to qualitative dimensions like the social, environmental, legal, and political impacts during the evaluation process [29]. Levin and Mcewan [56] urged to analyze the socioeconomic costs and benefits through the cost benefit or cost-effectiveness analysis. Other research endeavors aimed at addressing the qualitative aspects during PPP evaluation include the development of a project scoring table [2], spider web diagram [66], and decision support framework [64]. However, their applications were confined to the appraisal of proposals at the procurement stage, and none of these models can cater for the diverse interests of stakeholders.

\section{B. Evaluation Factors}

Rogers [71] argued that the compilation of evaluation factors is a critical step in conducting a feasibility study for PPP projects, and CSFs could serve well as determinants for PPP feasibility evaluation [18]. With reference to previous research in this area (e.g., [30], [32], [48], [66], [69], [76], [78], and [88], a total of 36 evaluation factors relevant to the feasibility stage of PPP schemes were drawn up. These evaluation factors can be classified into five categories (see Table I): 1) technical; 2) financial and economic; 3) social; 4) political and legal; and 5) others, according to different aspects of risk involved in a PPP project as identified by Ozdogan and Birgonul [64]. Further details about the identified evaluation factors with citations can be found in $\mathrm{Ng}$ and Wong [61].

1) Category 1-Technical: PPP would not be considered as an attractive option if the requirements and technologies continuously change during the expected lifespan of the project, unless sufficient flexibility is built into the contract to facilitate such changes. The experience of the public and private partners in a PPP scheme is also critical to success, as it can help to resolve how the scheme should be packaged and delivered, especially when it is complex and sensitive in nature [47]. Pearson [66] considered the prospect of creating innovative solutions as influential, if value-for-money is to be achieved. When the consortium is to be financially rewarded based on their performance, decision makers should assess whether service quality can be objectively defined and measured before considering the use of the PPP approach [25].

2) Category 2 - Financial and Economic: Hambros [36] postulated that the fundamental consideration of any PPP 
TABLE I

EVALUATION FACTORS FOR STUdYING THE FEASIBILITY OF PPP PROJECTS OBTAINED From VARIOUS LiteratURES

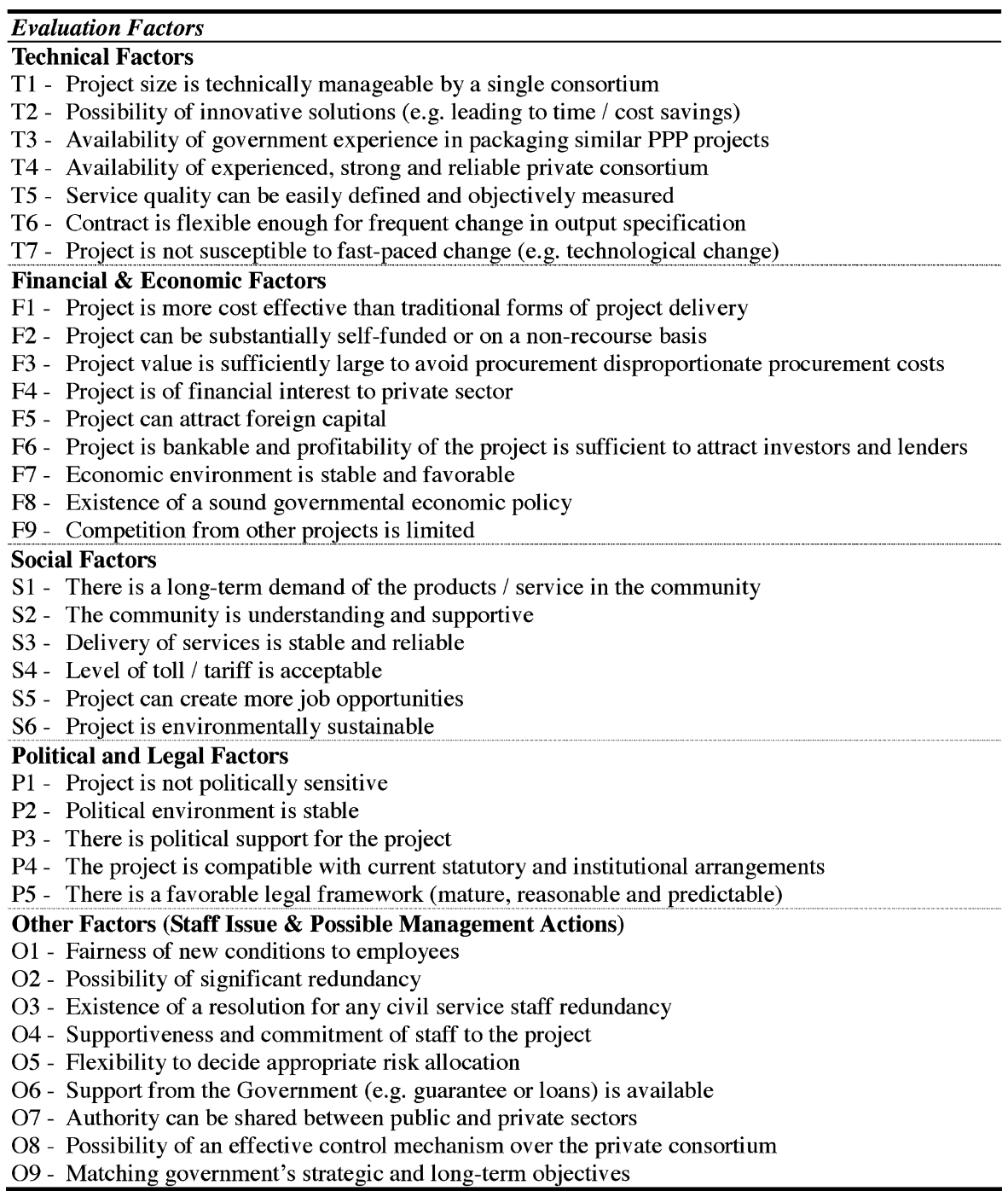

schemes is whether they can offer a cost-effective solution over other forms of project delivery, and this necessitates a careful scrutiny of the financial and economic factors. In order for the partnership to be attractive to investors, a PPP project must be self-sustainable, financially viable, and profitable [27], which in turn, depends largely on the economic environment, government policy, and severity of competition [35]. Foreign capital will only be flowing in, when a PPP scheme is of significant financial interest and of a reasonable scale, given the extra costs involved in the procurement process.

3) Category 3 - Social: As social acceptance is indispensable in today's society, the government should never commission a PPP scheme for the sake of expediting the facilities or services provision without satisfying the requirements and expectations of the community [37]. Citizens are more cautious about the service quality, charges, environmental impact, job opportunities, etc. when the facilities or services are delivered through the PPP mode [27]. As a result, engaging the public to make them realize the potential impacts and benefits of the scheme, and hopefully gaining their trust and support at the end would be of significant importance [40].

4) Category 4-Political and Legal: A lack of political support is considered a potential barrier to PPP projects [87], and a PPP scheme may be turned down if it is politically sensitive [25]. From the investors' perspective, consideration into a PPP project's political and legal feasibility prior to submitting a concession proposal is essential, as any changes in the political environment or deviations in the legal framework/institutional arrangements would add to the uncertainties and increase the risk of failure in a project [7], [66].

5) Category 5 - Other: Examples of other miscellaneous factors not covered in the preceding categories include the staff issues and the management actions of the government. Concerns regarding staff commitment and support would be inevitable as the sustainability of the project would have a direct impact on the job security of the staff involved in the project [17]. It is therefore, desirable to come up with a mutually acceptable resolution on the career prospect of civil servants, including seeking the consortium to absorb some of the redundant 
TABLE II

DETERMINANTS OF STAKEHOLDERS' SATISFACTION IN PPP PROJECTS

\begin{tabular}{|c|c|c|}
\hline \multicolumn{2}{|c|}{ Determinants of Stakeholders' Satisfaction } & \multirow{2}{*}{$\begin{array}{l}\text { References } \\
\text { Akintoye } \text { et a.l [1]; Kanji [50]; Campbell and } \\
\text { Finch [16] }\end{array}$} \\
\hline SAT1 & The service provided is of high quality & \\
\hline SAT2 & The service delivery is prompt, stable and reliable & $\begin{array}{l}\text { Akintoye et al. [1]; Kanji [50]; Campbell and } \\
\text { Finch [16] }\end{array}$ \\
\hline SAT3 & The cost of the service is reasonable & Akintoye et al. [1]; Kanji [50] \\
\hline SAT4 & $\begin{array}{l}\text { There is time saving in the construction of the } \\
\text { facilities }\end{array}$ & Bryde and Robinson [15] \\
\hline SAT5 & $\begin{array}{l}\text { There is cost saving in the construction of the } \\
\text { facilities }\end{array}$ & Bryde and Robinson [15] \\
\hline SAT6 & There are innovative solutions in the project & Kanji [50] \\
\hline SAT7 & $\begin{array}{l}\text { Private sector can meet the output requirements } \\
\text { specified in the contract }\end{array}$ & Bryde and Robinson [15] \\
\hline SAT8 & $\begin{array}{l}\text { The project creates business opportunities for the } \\
\text { private sector }\end{array}$ & Akintoye et al. [1]; Kanji [50] \\
\hline SAT9 & $\begin{array}{l}\text { Reasonable revenue can be generated for the } \\
\text { private sector }\end{array}$ & Nijkamp et al. [63]; Kanji [50] \\
\hline SAT10 & $\begin{array}{l}\text { A good relationship can be built between the } \\
\text { public and private sector }\end{array}$ & $\begin{array}{l}\text { Bryde and Robinson [15]; Peters and Phillips } \\
\text { [67] }\end{array}$ \\
\hline SAT11 & $\begin{array}{l}\text { The procurement procedure is fair, open and } \\
\text { transparent }\end{array}$ & $\begin{array}{l}\text { Akintoye et al [1]; Nijkamp et al. [63]; } \\
\text { Campbell and Finch [16] }\end{array}$ \\
\hline SAT12 & $\begin{array}{l}\text { There is a level playing field in the market } \\
\text { between similar projects }\end{array}$ & Hurst and Reeves [45] \\
\hline SAT13 & $\begin{array}{l}\text { There is an efficient channel of communication } \\
\text { between the community and the service provider }\end{array}$ & Campbell and Finch [16] \\
\hline
\end{tabular}

employees at reasonable employment terms [27]. Furthermore, the risks of a PPP scheme shall be equitably allocated between the government, private investors and to a certain extent the society to avoid any party from being disadvantaged [2]. Reasonable support from the government in the form of loans or guarantees shall be provided to make a PPP project more financially attractive and viable.

\section{Measuring Success of PPP Through Stakeholders' Satisfaction}

Having identified the factors that can influence the initial feasibility of PPP schemes, the next logical step would be to examine how they would lead to overall project success. In general, success in PPP schemes can be characterized as offering greater value-for-money, cost savings, reduction in construction time, more effective solutions, better relationship between the public and private sectors, maintaining a high level of service quality, etc. [1]. Nonetheless, a PPP project is regarded as being successful only if the key interests of all stakeholders are satisfied; therefore, the degree of stakeholders' satisfaction should be a more reliable measure of PPP project success [55]. Achieving this would necessitate a better appreciation of the interests of various stakeholders involved in a PPP project [84]. Table II summarizes the features pertaining to stakeholders' satisfaction as identified in the literature.

\section{RESEARCH METHODOLOGY}

\section{A. Research Framework}

The framework adopted in this research is illustrated in Fig. 2. A comprehensive literature review was conducted to uncover various decision models developed for evaluating the feasibility of PPP schemes as well as to identify the evaluation factors for this type of decisions and the features portraying stakeholders' satisfaction. To gain better understanding on current practices, and to verify the appropriateness of the list of evaluation factors and the satisfaction measures, pilot interviews were carried out. Being a pilot exploratory study, semistructured interviews were conducted with four experienced practitioners selected through purposive sampling [68], who have extensive knowledge and experience in PPP projects. The profiles of the interviewees are shown in Table III.

A questionnaire protocol was designed based on the evaluation factors and satisfaction measures as previously identified. Six industry practitioners who have more than five year experience in carrying out PPP projects representing public agencies and private investors, together with four citizens randomly selected from the general public were invited to pilot the questionnaire, and they were asked to comment on the questionnaire design and to rate the identified evaluation factors, as well as the satisfaction measures to determine if they are legible and adequately comprehensive [21].

Using a stratified sampling approach, respondents were classified into three groups: 1) the government; 2) private sector; and 3) and community groups. The questionnaires were directly distributed to the selected individuals via postal mail or email. The private sector group covers industry practitioners, such as developers, consultants, contractors, and investment bankers who are experienced in PPP schemes, while officers in relevant government departments were targeted. To ensure that respondents from the community appreciate the purpose of this study, a brief introduction about the concept of PPP and the research objectives were incorporated in the survey package. 


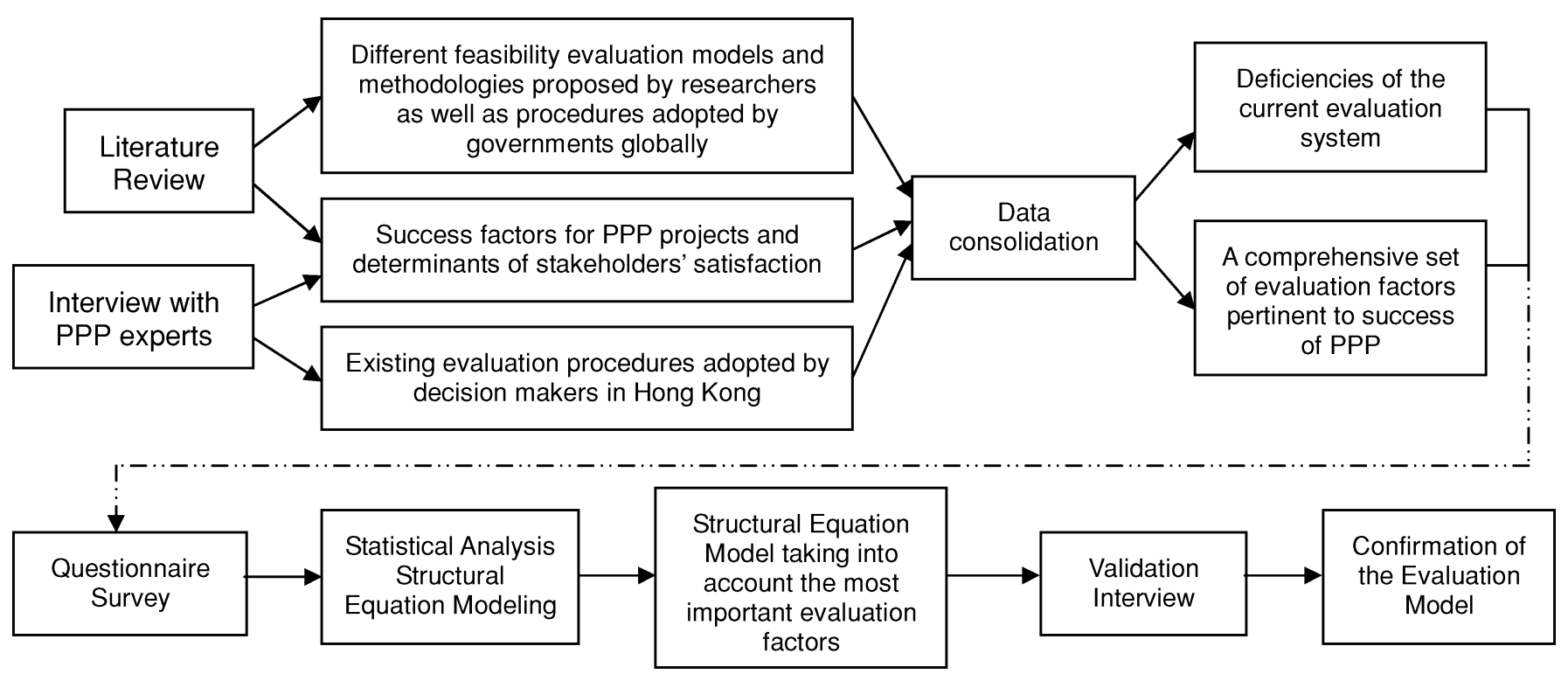

Fig. 2. Research approach.

TABLE III

PROFILES OF INTERVIEWEES FOR PILOT STUDY

\begin{tabular}{cccc}
\hline Interviewee & Designation & Organisation & Sector \\
\hline 1 & Assistant Director & Policy Bureau, HKSAR & Public \\
2 & Senior Engineer & Works Department, HKSAR & Public \\
3 & Chief Architect & Works Department, HKSAR & Public \\
4 & Head of Development & Main Contractor & Private \\
\hline
\end{tabular}

TABLE IV

RESPONSE RATE AND DISTRIBUTION OF THE SURVEY RESPONDENTS

\begin{tabular}{l|c|c|c|c}
\hline \hline & Government & $\begin{array}{c}\text { Private } \\
\text { sector }\end{array}$ & $\begin{array}{c}\text { General } \\
\text { public }\end{array}$ & Total \\
\hline $\begin{array}{l}\text { Number of blank } \\
\text { questionnaires sent out }\end{array}$ & 200 & 200 & 400 & 800 \\
\hline $\begin{array}{l}\text { Number of completed } \\
\text { questionnaires received }\end{array}$ & 48 & 80 & 53 & 181 \\
\hline Response rate & $24 \%$ & $40 \%$ & $13 \%$ & $23 \%$ \\
\hline Percentage in the sample & $27 \%$ & $44 \%$ & $29 \%$ & $100 \%$ \\
\hline \hline
\end{tabular}

Altogether 800 questionnaires were administered in Hong Kong, out of which, 181 valid responses were received representing a response rate of 23 percent. Table IV shows the detailed breakdown of the survey sample. Over 83 percent of the respondents from the government and private sector groups had over five years of relevant practical experience, and 36 percent of them had work in the industry for more than 15 years.

Descriptive analysis was first carried out on the collected data, using the statistical software statistical package for the social sciences (SPSS) in which the means and standard derivations (s.d.) were computed. A framework was then developed through the SEM approach to unveil the relationships between various evaluation factors pertinent to a PPP feasibility study and the level of overall satisfaction of stakeholders. Finally, eight experts from the government and private sectors were invited to participate in the validation interviews to review the results derived from the evaluation framework. The profiles of the experts involved in the validation interviews are summarized in Table V. The opinions of academics specializing in project procurement and/or public policies including those from the schools/departments of politics and public administration, engineering, construction and land use, and building science and technology in different universities were solicited to replicate the general publics' views. During the interviews, the findings from the descriptive analysis and the developed evaluation framework were presented to the experts and academics, and they were asked to rate the degree of agreement on the model's relevancy and to comment on the results obtained so as to confirm their accuracy and suitability. 
TABLE V

PROFILES OF INTERVIEWEES

\begin{tabular}{cccc}
\hline Interviewee & Designation & Organization & Sector \\
\hline 1 & Senior Engineer & Works Department & Public \\
2 & Project Engineer & Works Department & Public \\
3 & Head Of Department & Main Contractor & Private \\
4 & Project Engineer & Developer & Private \\
5 & Managing Director & Quantity Surveying & Private \\
6 & Professor & Tertiary Education Institute & Community \\
7 & Associate Professor & Tertiary Education Institute & Community \\
8 & Professor & Tertiary Education Institute & Community \\
\hline
\end{tabular}

To ensure that the information collected from the validation interviews are useful and valuable, local industry practitioners with extensive hands-on experience (at least five years) in indigenous PPP projects, at the managerial positions, were approached. The interviewees were identified through various sources, including authors' network, a search of previous PPP project participants from the public domain, and also referrals from the interviewees who also met the criteria for inclusion in this study. For those in the academic field, analogous criteria were applied for the selection of interviewee, i.e., extensive research experience (at least five years) in the field of PPP.

\section{B. Structural Equation Modeling}

The SEM approach was used to unveil the relationship between initial feasibility and the overall success of PPP projects as it is considered as an effective method for establishing the structural relationships among the latent variables, and for testing the hypothetical model. SEM is a multivariate analysis technique that encompasses various statistical methods, including the confirmatory factor analysis, multiple linear regression, path analysis, analysis of variance, etc. [38], [57]. SEM has been used in the engineering and management domain to examine, for instance, the relational bonding in interorganizational collaborations [72], factors affecting disputes between owners and contractors [59], satisfaction of construction project participants [55], effectiveness of project planning [46], and level of partners' trust and partnering success [83]. The general SEM can be represented by three matrix equations from Karl and Dag [51]

$$
\begin{aligned}
\eta_{(m x l)} & =B_{(m x m)} \times \eta_{(m x l)}+\Gamma_{(m x n)} \times \xi_{(n x l)}+\varsigma_{(m x l)} \\
y_{(p x l)} & =\Lambda_{y(p x m)} \times \eta_{(m x l)}+\varepsilon_{(p x l)} \\
x_{(q x l)} & =\Lambda_{x(q x n)} \times \xi_{(n x l)}+\delta_{(q x l)}
\end{aligned}
$$

Two main types of variables are used in a SEM, namely the measured and latent variables. Measured variables are observable and can be directly measured, while the latent variables are hypothetical or theoretical constructs, which shall be inferred from the measured variables. Since relationships between different variables within a SEM can be very complicated, path diagrams are prepared to illuminate these relationships. In the path diagrams, the latent and measure variables are represented in ovals and rectangles, respectively, while arrows are used to connect the variables and represent the causal flow of relations.
The one-headed arrows signify the regression relationships with the direction of the arrow implying the direction of influence, and the double-headed arrows symbolizing the intercorrelation between variables.

A SEM consists of the measurement and structural models. The measurement model gives the relationships between the latent and observed variables [13], while the structural model shows the relationships among latent variables. According to Garson [31], the process of SEM involves two main steps. The first step confirms the validity of the indicators in measuring the latent variables. In this study, the five categories of evaluation factors were derived from literature and were verified through the interviews with the experts. The indicators for measuring the latent factors were then checked by confirmatory factor analysis using SEM. The second step is to fit the factors and indicators into the structural model in order to establish the relationship between the variables through the regression or path analysis with the latent variables in the structural model.

Variables with low correlations are eliminated to improve the goodness-of-fit of the model [20], [72]. Using the software package AMOS 5.0, modification indexes are provided to assist model modification by adding possible paths between variables. These steps are repeated until a best-fit model is obtained, so that all goodness-of-fit indexes reach the recommended levels. Several fit indexes were adopted to assess the fitness of the SEM models. The chi-square model $\chi^{2}$, is the most common and popular fit index [43], and a nonsignificant $\chi^{2}$ can demonstrate that the specified model is not a null model [42], [52]. Other fit indexes adopted include the Tuker-Lewis index (TLI) [12], root mean squared residual (SRMR) [9], root mean squared error of approximation (RMSEA) [74], normed fit index (NFI) [10], and comparative fit index (CFI) [8].

An initial tripartite unified model showing the relationships between the evaluation factors at the initial feasibility stage and the stakeholders' satisfaction based on the SEM approach is shown in Fig. 3. All the evaluation factors and satisfaction measures as listed in the questionnaire are regarded as observed variables and given in rectangles, and the five categories are used to measure the latent factors in the SEM. Each of these five categories and their corresponding success factors are then connected by one-headed arrows to represent the direction of hypothesized influence [59]. For instance, the technical category can be manifested by seven evaluation factors (i.e., T1 to T7), and the arrows are originated from the latent technical category shown in oval to the seven measured technical factors in rectangles. 


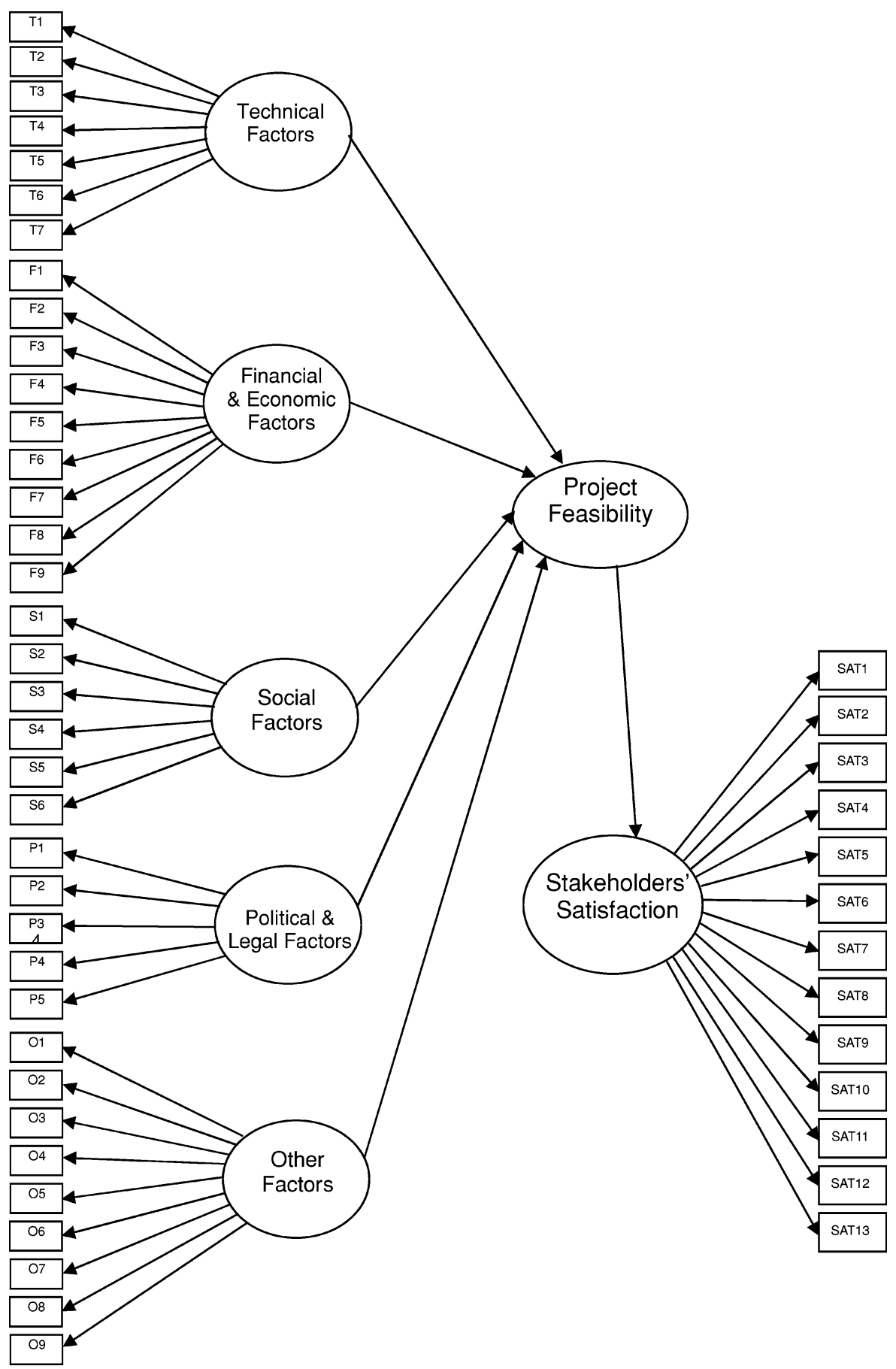

Fig. 3. Hypothetical structural equation model.

The initial feasibility of a PPP projects can then be assessed by considering the five categories of evaluation factors. In other words, addressing these evaluation factors would contribute to initial feasibility, and hence, the overall project success. Since a PPP project is successful only if all stakeholders are satisfied with the project, it was hypothesized that a relationship exists between the feasibility of a PPP project to the overall stakeholders' satisfaction on the project. All of these relationships are represented in the schematic model in Fig. 3 and were analyzed by the SEM approach. Certain two-headed arrows were added between the five categories of evaluation factors to examine the degree of interrelationship between them although these arrows are not shown in Fig. 3 due to the legibility.

Despite debates on the sample size for SEM analysis, especially as the complexity of the model grows, there has been no consensus on what is regarded as reasonable. Different rules of thumb had been proposed by researchers to warrant the stability of a SEM, and these include soliciting 15 cases per measured variables [75] or 10 cases per parameter with a minimum critical ratio of 5:1 [52]. However, Bentler and Chou [11] argued that a 
ratio of as low as five cases per parameter is also acceptable if the collected data is reliable. As a general guideline, Kline [52] considered a sample size less than 100 as small; between 100 and 200 as medium, and greater than 200 as large. Therefore, the sample size of 181 cases in this study should be sufficient to support a stable model.

\section{FINDINGS}

\section{A. Significant Evaluation Factors and Satisfaction Measures}

The relative importance of the evaluation factors and satisfaction measures as perceived by the three groups of respondents is analyzed by referring to the mean ratings (see Table VI). In general, all evaluation factors and satisfaction measures have a mean rating higher than four (i.e., above the midpoint along the 7-point Likert scale) indicating that they are critical to the success of a PPP project and relevant for portraying stakeholders' satisfaction.

In particular, an "acceptable level of toll/tariff" (S4) is the most important factor $($ mean $=5.78$, s.d. $=1.11)$ when assessing the feasibility of a PPP project. This concurs with H. M. Treasury [40] that reasonable toll is imperative to a PPP scheme. In addition, the "existence of a long-term demand of the services in the community" ( $\mathrm{S} 1)$ (mean $=5.72$, s.d. $=1.23)$ and having a "stable and reliable delivery of services" $(\mathrm{S} 3)($ mean $=5.71$, s.d. $=1.04)$ are also perceived by the respondents as important social factors.

Respondents considered the "availability of experienced, strong, and reliable private consortium" (T4) (mean $=5.72$, s.d. $=0.90)$ as an important technical factor leading to PPP success. This is in line with Tam's [76] view, who pointed out that a large and reliable consortium with experienced organizational set up is the key ingredient of a successful PPP project. PPP allows the public agencies to tap on the technical, management, and financial expertise of the private sector, and this could help improve the cost and schedule assurance, enhance service delivery, and gain access to private capital.

Predictably, "profitability of a PPP project" (F4) (mean = 5.67 , s.d. $=1.26)$ was considered a vital financial and economic factor in attracting private sector investment. In contrast, "matching with government's strategic and long-term objectives" (O9) (mean $=5.71$, s.d. $=1.10)$ is considered by the public sector as critical. A successful PPP project should be one in which the facilities or services are delivered in a "successful, prompt, stable, and reliable" manner (SAT2) (mean = 5.93 , s.d. $=1.01$ ) and of "high-quality service" standard (SAT1) $($ mean $=5.80$, s.d. $=0.96)$.

\section{B. Development of a Comprehensive Feasibility Model}

As expected, the general SEM established did not appear to fit well with the data, as it is merely an initial model. Based on this preliminary model, several attempts of refinement were made to improve the model fit with the evaluation factors having a low correlation to the latent factors being removed from the model. Factors removed from the refined model include T1, T3, T5, T6, and T7 in the technical category; F1 to F5, and F9
TABLE VI

MeAns and s.d. OF the ProJect SUCCESS AND SATISFACtion Factors

\begin{tabular}{|c|c|c|c|}
\hline \multirow[t]{2}{*}{ Factors } & & \multicolumn{2}{|c|}{ Overall } \\
\hline & & Mean & s.d. \\
\hline \multirow[t]{7}{*}{ Technical } & T1 & 5.00 & 1.39 \\
\hline & $\mathrm{T} 2$ & 5.30 & 1.12 \\
\hline & $\mathrm{T} 3$ & 5.13 & 1.20 \\
\hline & $\mathrm{T} 4$ & 5.72 & 0.90 \\
\hline & T5 & 5.27 & 1.09 \\
\hline & T6 & 5.06 & 1.38 \\
\hline & $\mathrm{T} 7$ & 4.52 & 1.18 \\
\hline \multirow[t]{9}{*}{ Financial and economic } & F1 & 5.66 & 1.19 \\
\hline & $\mathrm{F} 2$ & 5.35 & 1.24 \\
\hline & F3 & 5.09 & 1.10 \\
\hline & $\mathrm{F} 4$ & 5.67 & 1.26 \\
\hline & F5 & 4.65 & 1.34 \\
\hline & F6 & 5.47 & 1.14 \\
\hline & F7 & 5.14 & 1.24 \\
\hline & F8 & 5.30 & 1.15 \\
\hline & F9 & 4.31 & 1.32 \\
\hline \multirow[t]{6}{*}{ Social } & S1 & 5.72 & 1.23 \\
\hline & S2 & 5.62 & 1.17 \\
\hline & S3 & 5.71 & 1.04 \\
\hline & S4 & 5.78 & 1.11 \\
\hline & S5 & 4.95 & 1.35 \\
\hline & S6 & 5.13 & 1.12 \\
\hline \multirow[t]{5}{*}{ Political and legal } & P1 & 4.93 & 1.27 \\
\hline & $\mathrm{P} 2$ & 5.10 & 1.08 \\
\hline & P3 & 5.18 & 1.19 \\
\hline & P4 & 5.20 & 1.09 \\
\hline & P5 & 5.34 & 1.00 \\
\hline \multirow[t]{9}{*}{ Other } & O1 & 4.98 & 1.12 \\
\hline & $\mathrm{O} 2$ & 4.76 & 1.05 \\
\hline & $\mathrm{O} 3$ & 4.81 & 1.23 \\
\hline & O4 & 5.10 & 1.18 \\
\hline & O5 & 5.31 & 1.11 \\
\hline & O6 & 5.06 & 1.25 \\
\hline & $\mathrm{O} 7$ & 5.10 & 1.19 \\
\hline & O8 & 5.56 & 1.18 \\
\hline & O9 & 5.71 & 1.10 \\
\hline \multirow[t]{13}{*}{ Satisfaction } & SAT1 & 5.80 & 0.96 \\
\hline & SAT2 & 5.93 & 1.01 \\
\hline & SAT3 & 5.74 & 1.16 \\
\hline & SAT4 & 5.13 & 1.10 \\
\hline & SAT5 & 5.35 & 1.12 \\
\hline & SAT6 & 5.18 & 1.11 \\
\hline & SAT7 & 5.52 & 1.05 \\
\hline & SAT8 & 5.22 & 1.24 \\
\hline & SAT9 & 5.08 & 1.28 \\
\hline & SAT 10 & 4.92 & 1.36 \\
\hline & SAT11 & 5.52 & 1.24 \\
\hline & SAT12 & 5.29 & 1.25 \\
\hline & SAT13 & 5.29 & 1.10 \\
\hline
\end{tabular}

in the financial and economic category; $\mathrm{S} 1$ and $\mathrm{S} 5$ in the social category, P4 and P5 in the political and legal category; O3, O5 to O9 in the other category; as well as SAT1, SAT4, SAT5, SAT6, SAT8, SAT9, and SAT10 related to stakeholders' satisfaction. The validity and reliability of the indicators in measuring the latent factors were confirmed by confirmatory factor analysis using SEM. 


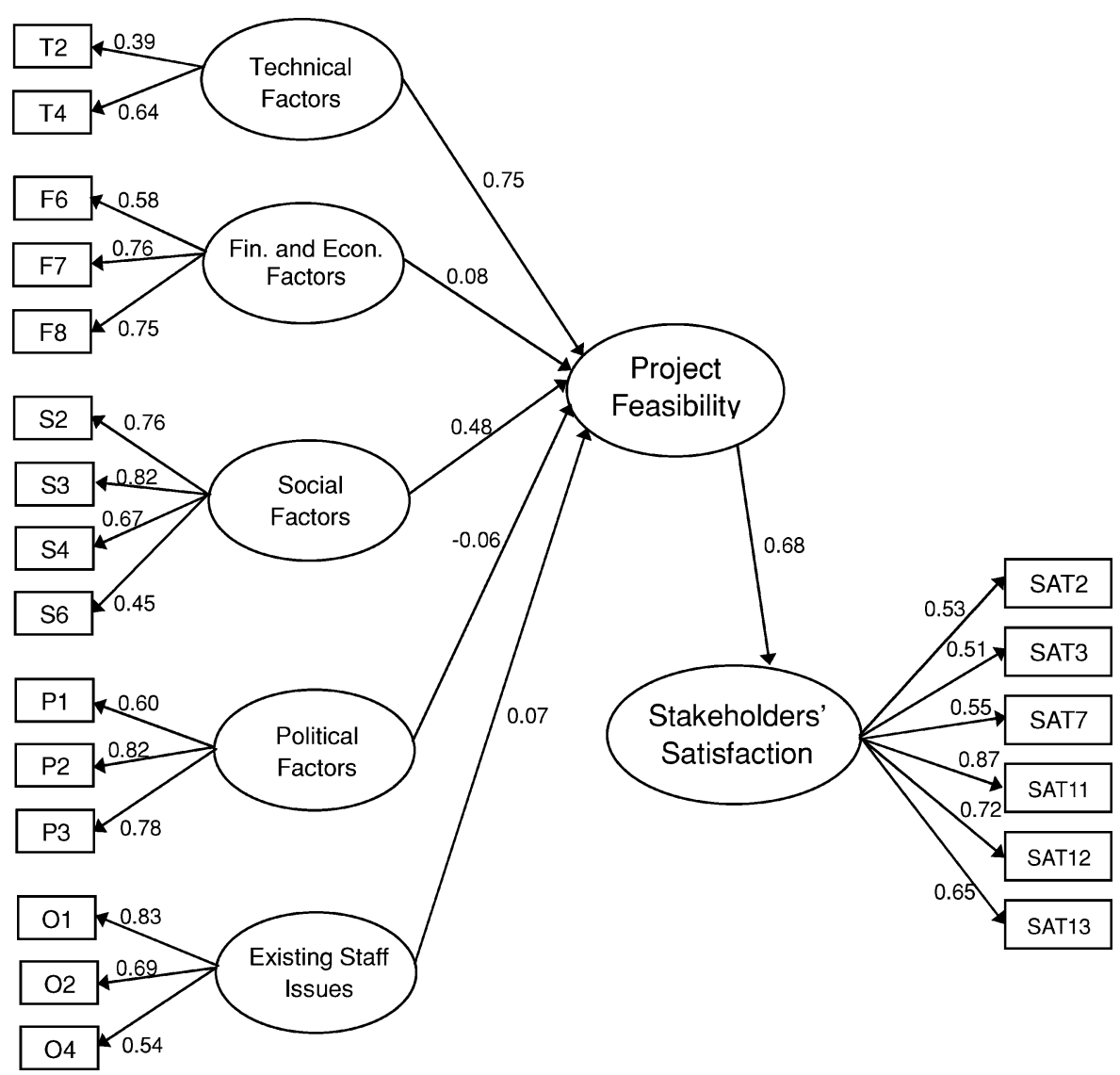

Fig. 4. Standardized regression weights of final tripartite structural equation model.

TABLE VII

FIT INDEXES FOR THE TRIPARTITE STRUCTURAL EQUATION MODEL

\begin{tabular}{lllc}
\hline Goodness-of-fit measure & Recommended level of GOF measure & References & Final SEM \\
\hline$\chi 2$ / degree of freedom & Recommended level from 1 to 2 & $\begin{array}{l}\text { Holbert and Stephenson } \\
{[42]}\end{array}$ & 1.797 \\
& & Browne and Cudeck & 0.067 \\
$\begin{array}{c}\text { Root mean square error of } \\
\text { approximation (RMSEA) }\end{array}$ & $\begin{array}{c}<0.05 \text { indicates very good fit } \\
\text { (Threshold level = 0.10) } \\
\text { p-value for hypothesis test of }\end{array}$ & {$[14]$} & 0.013 \\
$\begin{array}{c}\text { PCLOSE } \\
\text { RMSE <0.05 }\end{array}$ & Ashok [3]; Hu and & 0.867 \\
$\begin{array}{l}\text { Tucker-Lewis index (TLI) } \\
\text { Comparative fit index }\end{array}$ & 0 (no fit) to 1 (perfect fit) 1 (perfect fit) & Bentler [44]; & 0.891 \\
$\begin{array}{l}\text { (CFI) } \\
\text { Normal fit index (NFI) }\end{array}$ & 0 (no fit) to 1 (perfect fit) & & 0.789 \\
\hline
\end{tabular}

Since all of the evaluation factors related to the legal aspect were eliminated after the refinement process, the original political and legal category was renamed as the political category. While the observed factors remained in the 'other' category are all related to existing staff issues, this category was thus named accordingly. Apart from eliminating certain factors, the modification indexes also confirmed the presence of interrelations between the error terms of SAT2 and SAT3, as well as the error terms of SAT12 and SAT13, and the model should be improved by adding these interrelations. Fig. 4 shows the final model, while Table VII highlights the results of the goodnessof-fit tests of the final model. All the fit indexes fall within the recommended intervals, solidifying the reliability of the model.
In reference to the PPP feasibility evaluation framework (see Fig. 4), it is suggested that five categories of factors should be considered by decision makers. The results indicate that the technical feasibility can be adequately measured by the "possibility of innovative solutions" (T2) and "availability of experienced, strong, and reliable private consortium in the market" (T4). To determine the financial and economic feasibility, "bankability and profitability of the project" (F6), "existence of a favorable and stable economic environment" (F7) and "a sound governmental economic policy" (F8) shall be examined. "Understanding and support of the community" (S2), "reliability and stability of service delivery" (S3), "reasonableness of toll/tariff" (S4), and "environmental sustainability" (S6) shall be considered for the social feasibility. Political feasibility is represented by the 
TABLE VIII

Correlation COEFFicients BetweEn the Latent Factors

\begin{tabular}{lclc}
\hline Correlation Path & & & Estimate \\
\hline Technical & $\leftarrow \rightarrow$ & Financial and economic & 0.527 \\
Financial and economic & $\leftarrow \rightarrow$ & Social & 0.220 \\
Social & $\leftarrow \rightarrow$ & Political & 0.333 \\
Other & $\leftarrow \rightarrow$ & Political & 0.160 \\
Other & $\leftarrow \rightarrow$ & Social & 0.583 \\
Other & $\leftarrow \rightarrow$ & Financial and economic & 0.070 \\
Other & $\leftarrow \rightarrow$ & Technical & 0.300 \\
Financial and economic & $\leftarrow \rightarrow$ & Political & 0.613 \\
Technical & $\leftarrow \rightarrow$ & Political & 0.368 \\
Technical & $\leftarrow \rightarrow$ & Social & 0.138 \\
e38 (SAT2) & $\leftarrow \rightarrow$ & e39 (SAT3) & 0.406 \\
e48 (SAT12) & $\leftarrow \rightarrow$ & e49 (SAT13) & 0.220 \\
\hline
\end{tabular}

"political sensitivity of the project" (P1), "stability of political environment" (P2), and "political support to the project" (P3). Finally, staff issue shall be measured by the "fairness of new conditions to employees" (O1), "possibility of significant staff redundancy" $(\mathrm{O} 2)$, and "supportiveness and commitment of the staff to the project" $(\mathrm{O} 4)$.

As for stakeholders' satisfaction on PPP projects, decision makers should measure the achievement of the following performance indicators: "prompt, stable, and reliable service delivery" (SAT2), "reasonable cost of service" (SAT3), "meeting output requirements specified in contract" (SAT7), "fair, open, and transparent procurement procedures" (SAT11), "a level playing field in the market" (SAT 12), and "an efficient channel of communication between the community and service provider" (SAT13).

Among the five categories of evaluation factors for initial feasibility evaluation, the technical and social categories (standardized coefficients $=0.75$ and 0.48 , respectively) are more important than the others. Greater efforts should be made to evaluate the technical and social viability when conducting feasibility studies for PPP projects.

The SEM also showed a strong relationship between the initial feasibility of a PPP project and stakeholders' satisfaction on the project (standardized coefficient $=0.68$ ). The relationship between the technical feasibility and stakeholders' satisfaction can be obtained by multiplying the two standardized coefficients $(0.75 \times 0.68=0.51)$. The correlation coefficient between the social feasibility and stakeholders' satisfaction can be derived in similar fashion $(0.48 \times 0.68=0.33)$.

Table VIII highlights the intercorrelations between the five categories of latent evaluation factors. All the five categories were shown to be intercorrelated to some degrees. Strong interrelations were found between political and financial and economic factors (correlation coefficient $=0.61$ ); social and staff factors (correlation coefficient $=0.58$ ); as well as technical and financial and economic factors (correlation coefficient $=0.53$ ).

\section{DISCUSSIONS}

The SEM indicates the relative importance of the evaluation factors and provides a comprehensive framework for the evaluation of the PPP projects' feasibility. The predictors for PPP project success were also determined to enrich the knowledge base and help to formulate management strategies to better implement the PPP project delivery approach. The final SEM shows that the technical and social feasibility are crucial to the success of PPP schemes after taking into account the interests of all the stakeholders. The results are indeed contrary to the general belief of most researchers and practitioners in PPP, in which the financial merits of the schemes are conceived as paramount important to project success. No wonder many previous studies emphasized on the financial viability of PPP projects alone.

In today's society, being accountable toward the public alone is no longer adequate, as PPP schemes are susceptible to severe political and social scrutiny if the government is not mindful of the soft issues [29]. To avoid from accused of transferring public interest to the private sector, social aspects like the social acceptance, reliable and stable service, tariff and toll fairness, political and legal concerns, environmental impacts, staff issues, etc. must be carefully considered and addressed by the government prior to the execution of any PPP schemes. Overlooking the social issues could lead to the abortion of a PPP scheme, and hence, undermine the credibility of the government.

The technical strengths of the private consortium, in particular, their ability to come up with innovative solutions is also critical to the success of PPP projects. A noteworthy example of the importance of promoting innovation is the environmental awareness of the public sector in the United Kingdom [23], where policies and strategies have been formulated within the PPP framework to promote environmental innovation and strategic environmental assessment [33], [70]. Unfortunately, without proper recognition during the procurement and operational stages, technological innovations may be left out. In order to maximize the benefits of PPP to different stakeholders, technological innovations should be encouraged through an equitable rewarding mechanism.

\section{VALIDATION}

To confirm the accuracy of the analyses and the PPP feasibility evaluation framework developed in this study, eight PPP experts from the government, private sector, as well as people from the community were invited to participate in the validation interviews. Although the order of importance of the evaluation factors was subjected to some controversy, interviewees generally agreed with the results and confirmed the validity of the SEM model developed. All interviewees agreed that the five categories of evaluation factors and their corresponding factors are important to be considered during the feasibility stage of PPP projects. General agreement had also been attained on the relative importance of evaluation factors derived by the model despite the existence of some diverse opinions about the order of importance of the evaluation factors in the model. Some interviewees believed that the financial factors should still be the most important in the feasibility evaluation, and this is in line with the literature. The results of the SEM can encourage decision makers to think about the importance of other qualitative factors when assessing the feasibility of a PPP project.

The participants involved in the validation interviews were also asked to comment on the intercorrelations between the evaluation factors. They agreed that the technical and financial and 
economic categories; social and staff issues categories; as well as political and financial and economic categories are intercorrelated. This implies the existence of interdependency amongst various evaluation factors and the possibility of causing a ripple effect. Therefore, if the project is of financial interest to the private sector, for instance, it may increase the possibility of innovative solutions. Such relationship may also be applied to the indigenous political support and the environment.

It is believed that a PPP project is deemed successful only if all stakeholders involved are satisfied with the project. This statement was confirmed in the validation interview, since all interviewees agreed that satisfaction of stakeholders is a major success indicator of PPP projects. They also agreed that stakeholders' satisfaction can be better measured by the six indicators given by the SEM, including 1) prompt, stable, and reliable service delivery; 2) reasonable cost of service; 3 ) meeting of output requirement of the private sector; 4) fair, open, and transparent procurement procedure; 5) level playing field in the market; and 6) efficient channel of communication between the community and the service provider. Moreover, they also confirmed the importance of a comprehensive feasibility study to the overall success of a PPP project (with a contribution of up to $80 \%$ ). Hence, a comprehensive feasible study of a PPP project should address the evaluation factors identified in various dimensions and the project is only sustainable when it is economically viable, socially acceptable, and environmentally acceptable [37], [86].

\section{CONCLUSION}

The idea of involving the private sector for the provision of energy, telecommunications and infrastructure facilities, and services through the PPP approach is gaining traction in many areas across the world. This is under the belief that government should steer more and row less, and the philosophy of building up a large competitive market by restraining the size of civil service. The benefits of PPP stretch well into the realms of engineering management, since the PPP approach could provide opportunities for more efficient project management, proficient risk mitigation, and enhanced technological innovation, with contributions from the private sector.

With the aim to establish a comprehensive evaluation framework for decision makers to assess the initial feasibility of a PPP project, a model was developed by taking into account the interests of the government, private investor, and community so as to arrive at a feasible and mutually beneficial project outcome. Through a questionnaire survey conducted in Hong Kong and the SEM approach, relationships between the evaluation factors relevant to the initial feasibility of PPP projects and the overall satisfaction of stakeholders have been established. It was discovered that the initial feasibility of a PPP project has a high degree of contribution to the overall satisfaction of stakeholders. A comprehensive PPP evaluation framework with due consideration of public accountability, socioeconomic concerns, technical competence, and commercial interests would therefore, be indispensible to warrant a successful PPP scheme and promote genuine "partnership" amongst all parties.
The results of the SEM showed that the technical and social aspects are crucial to the feasibility of PPP projects when the interests of all stakeholders are taken into account. More research should be conducted to examine how to incorporate the technical and social aspects into the PPP feasibility evaluation, as well as the procurement and controlling mechanisms rather than simply focusing on the financial viability of the scheme. The evaluation factors found in the comprehensive feasibility evaluation framework can therefore, serve as a practical checklist of success for PPP projects, which can be further extended to benchmarking and control purposes. With that, the government and investors can identify the risks of PPP projects, so as to minimize the possibility of project failure. Furthermore, the essential features of a successful PPP project as identified in this paper can help decision makers to formulate management strategies to improve the implementation of PPP projects, which could result in the compilation of practical guidelines for enhancing the overall performance of PPP project delivery.

A successful PPP scheme should satisfy the needs of the community, the government, as well as the private consortium. In this paper, the authors have proposed an evaluation framework to examine the relationships between different evaluation factors (technical, economic, social, political, and legal aspects) and the overall satisfaction of stakeholders. The research findings could assist engineering managers to improve their understanding on the relative importance of the evaluation factors, and help to establish a comprehensive framework to evaluate the feasibility of PPP projects.

\section{ACKNOWLEDGMENT}

The authors are grateful to the Research Grants Council of the Government of Hong Kong Special Administrative Region for their financial support through the Public Policy Research Scheme (Grant No.: 7010-PPR-4).

\section{REFERENCES}

[1] A. Akintoye, C. Hardcastle, M. Beck, E. Chinyio, and D. Asenova, "Achieving best value in private finance initiative project procurement," Constr. Manage. Econ., vol. 21, no. 5, pp. 461-470, 2003.

[2] Y. Arikan, "Build operate transfer model for new power plants for Turkey," in Proc. 7th Mediterranean Electrontech. Conf. - MELECON, Antalya, Turkey: IEEE, Apr. 12-14, 1994, vol. 3, pp. 1089-1092.

[3] D. Ashley, R. Bauman, J. Carroll, J. Diekmann, and F. Finlayson, "Evaluation viability of privatized transportation projects," J. Infra. Syst., vol. 4, no. 3, pp. 102-110, 1998.

[4] J. Ashok, "Cognition, culture and competition: An empirical test of the learning organization," Learning Org., vol. 10, no. 1, pp. 31-50, 2003.

[5] M. Balat, H. Balat, and N. Acici, "Thermal-electricity power plants in Turkey," Energ. Explor. Exploit., vol. 22, no. 5, pp. 367-376, 2004.

[6] H. A. Bdelkhalek, I. Abullah, and A. Almershid, "Public private partnership approach in electrical projects - How to make a decision," Alexandra Eng. J., vol. 47, no. 2, pp. 201-210, 2008.

[7] E. Bennett. (1998). Public-Private Co-operation in the Delivery of Urban Infrastructure Services (Water and Waste), PPPUE Background Paper, UNDP/Yale Collaborative Programme [Online]. Available: http://www.undp.org./pppue

[8] P. M. Bentler, EQS: Structural Equations Program Manual. Los Angeles, CA: BMDP Statistical Software, 1989.

[9] P. M. Bentler, EQS Structural Equations Program Manual. Encino, CA: Multivariate Software, 1995. 
[10] P. M. Bentler and D. G. Bonett, "Significance tests and goodness of fit in the analysis of covariance structures," Psychol. Bull., vol. 88, pp. 588$606,1980$.

[11] P. M. Bentler and C. Chou, "Practical issues in structural modeling," Sociol. Methods Res., vol. 16, no. 1, pp. 78-117, 1987.

[12] K. A. Bollen, "A new incremental fit index for general structural equation models," Sociol. Methods Res., vol. 17, pp. 303-316, 1989.

[13] A. Boomsma, Structural Equation Modeling Introduction. The Netherlands: Department of Statistics and Measurement Theory, University of Groningen, 2005.

[14] M. W. Browne and R. Cudeck, "Alternative ways of assessing model fit," in Testing Structural Equation Models, K. A. Bollen and J. S. Long, Eds. Newbury Park, CA: Sage, 1993, pp. 136-162.

[15] D. J. Bryde and L. Robinson, "Client versus contractor perspectives on project success criteria," Int. J. Proj. Manage., vol. 23, no. 8, pp. 622-629, 2005

[16] L. Campbell and E. Finch, "Maintaining customer satisfaction: An organizational justice approach to facilitate management," in Proc. CIB-W70 Symp. Hum. Element Facility Manage. - Understanding Needs Our Customers, Kowloon Shangri-la Hotel, Hong Kong, Dec. 7-8, 2004, p. 12.

[17] A. P. C. Chan, D. W. M. Chan, Y. H. Chiang, B. S. Tang, E. H. W. Chan, and K. S. K. Ho, "Exploring critical success factors for partnering in construction projects," ASCE J. Constr., Eng. Manage., vol. 130, no. 2, pp. 188-198, 2004

[18] A. P. C. Chan, D. Scott, and A. P. L. Chan, "Factors affecting the success of a construction project," ASCE J. Constr., Eng. Manage., vol. 130, no. 1, pp. 153-155, 2004.

[19] R. Chellini, "First BOT combined-cycle plant in Vietnam," Diesel Gas Turbine Worldwide, vol. 36, no. 4, pp. 52-53, 2004.

[20] G. A. Churchill, "A paradigm for developing better measures of marketing constructs," J. Market. Res., vol. 16, no. 1, pp. 64-73, 1979.

[21] D. R. Cooper and P. S. Schindler, Business Research Methods. Irwin, Boston: McGraw-Hill, 2006

[22] CPSU, Factors Shaping Successful Pro-Poor ICT Public-Private Partnerships: Inception Phase of a Study in Commonwealth Developing Countries. London, U.K.: Commonwealth Policy Studies Unit Department of International Development, 2002.

[23] DEFRA (2007). Report of the Commission on Environmental Markets and Economic Performance. U.K.: Department for Environment, Food and Rural Affairs [Online]. Available: www.defra.gov.uk/environment/ business/commission/index.htm.

[24] DHHS, American Health Information Community Successor - White Paper, Department of Health and Human Services. Washington, DC, U.S.A: Office of National Coordinator for Health Information Technology, 2007.

[25] C. F. Duffield, "PPPs in Australia," in Proc. Public Private Partnerships Oppor. Challenges, Hong Kong: Hong Kong Convention and Exhibition Centre, Feb. 22, 2005, pp. 5-14.

[26] Efficiency Unit, Serving the Community by Using the Private Sector. Hong Kong: The Government of HKSAR, 2001.

[27] FIDIC, Project Financing Sustainable Solutions - Adding Value through Innovation Re-assessing the Priorities. Geneva, Switzerland: Federation Internationale des Ingenieurs Conseils, 2001.

[28] P. Foster, "Hydroelectric power generation privatization and private development: The role of the independent engineer," in Proc. Int. Conf. Hydropower, Atlanta, GA: ASCE Press, Aug. 5-8, 1997, pp. 1888-1895.

[29] M. Freeman, Critical Choices: The Debate over Public-Private Partnerships and What is Means for American's Future. Washington, DC: The National Council for Public-Private Partnerships, 2003.

[30] M. Frilet, "Some universal issues in BOT projects for public infrastructure," Int. Constr. Law Rev., vol. 14, no. 4, pp. 499-512, 1997.

[31] D. Garson, PA 765: Quantitative Research in Public Administration. Raleigh, NC: North Carolina State University, 2006.

[32] T. Grant, "Keys to successful public-private partnerships," Can. Bus. Rev., vol. 23, no. 3, pp. 27-28, 1996.

[33] S. E. Grasman, J. Faulin, and F. Lera-Lopez, "Public-Private Partnerships for technology growth in the public sector," in Proc. IEEE Int. Eng. Manag. Conf., Estori, Portugal: IEEE Press, Jun. 28-30, 2008, pp. 1-4.

[34] J. C. Grebe, Jr., "Effective engineering management in the next decade," in Proc. IEEE Int. Eng. Manag. Conf. Albany, NY: IEEE Press, Oct. 7-9, 2001, pp. 88-93.

[35] L. Grilo, C. Hardcastle, A. Akintoye, S. Silva, S. Melhado, and P. Edwards, "Challenges and opportunities for the Brazilian public private partnerships program," in Proc. Public Private Partnerships - Oppor. Challenges, Hong Kong: Hong Kong Convention and Exhibition Centre, Feb. 22, 2005, pp. 19-31.
[36] S. G. Hambros, Public-Private Partnerships for Highways: Experience, Structure, Financing, Applicability and Comparative Assessment. Ottawa, Canada: The Council, 1999.

[37] G. W. Heinke and J. K. C. Wei, "Innovative approaches to financing of initiatives such as sustainable infrastructure and building, planning, design, construction and operation," Consultancy for Asia Pacific Economic Cooperation (APEC), Final Rep., HKUST, Hong Kong, 2000.

[38] T. Hill and P. Lewicki, Statistics Methods and Application. Tulsa, OK StatSoft, 2006.

[39] H. M. Treasury, Public Private Partnerships: The Government Approach. London, U.K.: Stationery Office, 2000.

[40] H. M. Treasury, Value for Money Assessment Guidance. London, U.K.: Stationery Office, 2004.

[41] S. P. Ho and L. Y. Liu, "An option pricing-based model for evaluating the financial viability of privatized infrastructure projects," Constr. Manage. Econ., vol. 20, no. 2, pp. 143-155, 2002.

[42] R. L. Holbert and M. T. Stephenson, "Structural equation modeling in the communication sciences, 1995-2000," Hum. Commun. Res., vol. 28, pp. 531-551, 2002.

[43] R. H. Hoyle and A. T. Panter, "Writing about structural equation models," in Structural Equation Modeling, R. H. Hoyle, Ed. Thousand Oaks, CA: Sage, 1995, pp. 158-176.

[44] L. Hu and P. M. Bentler, "Cutoff criteria for fit indexes in covariance structure analysis: Conventional criteria versus new alternatives," Struct. Eq. Modeling, vol. 6, pp. 1-55, 1999.

[45] C. Hurst and E. Reeves, "ANN economic analysis of Ireland's first public private partnership," Int. J. Public Sector Manage., vol. 17, no. 5, pp. 379388, 2004.

[46] M. D. M. Islam and O. O. Faniran, "Structural equation model of project planning effectiveness," Constr. Manage. Econ., vol. 23, no. 2, pp. 215223, 2005.

[47] E. J. Jaselskis and D. B. Ashley, "Optimal allocation of project management resources for achieving success," ASCE J. Constr., Eng. Manage., vol. 117, no. 2, pp. 321-340, 1991.

[48] M. Jefferies, R. Gameson, and S. Rowlinson, "Critical success factors of the BOOT procurement system: Reflection from the Stadium Australia case study," Eng. Constr. Arch. Manage., vol. 9, no. 4, pp. 352-361, 2002.

[49] C. C. Kang, C. M. Feng, and S. C. Huang, "A new financial engineering model for analyzing the royalty of BOT projects: The Taiwan case," in Proc. IEEE Int. Conf. Ind. Eng. Eng. Manag., Singapore: IEEE Computer Society, Dec. 2-4, 2007, pp. 277-281.

[50] G. K. Kanji, "Performance measurement system," Total Quality Manage. vol. 13 , no. 5 , pp. 715-728, 2002.

[51] G. J. Karl and S. Dag, LISREL 8: Structural Equation Modeling with the SIMPLIS Command Language. Hillsdale, NJ: Lawrence Erlbaum Associates, 1996.

[52] R. B. Kline, Principles and Practice of Structural Equation Modeling, 2nd ed. New York: Guilford Press, 2005.

[53] R. Kuriyan and I. Ray, "Public-private partnerships and information technologies for development in India," in Proc. 2nd IEEE/ACM Int. Conf. Inf. Commun. Technol., Bangalore, India: IEEE, Dec. 15-16, 2007, pp. 310 320.

[54] W. J. Lannes, "What is engineering management?" IEEE Trans. Eng. Manag., vol. 48, no. 1, pp. 107-110, Feb. 2001.

[55] M. Y. Leung, S. T. Ng, M. Skitmore, and S. O. Cheung, "Measuring construction project participant satisfaction," Constr. Manage. Econ., vol. 22, no. 3, pp. 319-331, 2004.

[56] H. M. Levin and P. J. Mcewan, Cost-effectiveness Analysis: Methods and Applications, 2nd ed. Thousand Oaks, CA: Sage, 2001.

[57] G. A. Marcoulides and R. E. Schumaker, Advanced Structural Equation Modeling: Issues and Techniques. Mahwah, NJ: Erlbaum Associates, 1996.

[58] R. W. McQuaid, "The theory of partnership: Why have partnerships?" in Public Private Partnerships: Theory and Practice in International Perspective, S. P. Osborne, Ed. London, U.K.: Routledge, 2000.

[59] K. Molenaar, S. Washington, and J. Diekmann, "Structural equation model of construction contract dispute potential," ASCE J. Constr., Eng. Manage., vol. 126, no. 4, pp. 268-277, 2000.

[60] L. C. Morse and D. L. Babcock, Managing Engineering and Technology: An Introduction to Management for Engineers. Upper Saddle River, NJ: Prentice-Hall, 2007.

[61] S. T. Ng and Y. M. W. Wong, "Integrating social aspects when evaluating the feasibility of public private partnership schemes," in Proc. 12th Pac Assoc. Quantity Surveyors Congr., Edmonton, Alberta, Jun. 16-18, 2008, p. 8 . 
[62] S. Nicholson, "Highways agency traffic control centre project," in Proc 10th Int. Conf. Road Transp. Inf. Control, London, U.K.: Institution of Electrical Engineers, Apr. 4-6, 2000, pp. 70-74.

[63] P. Nijkamp, M. V. D. Burch, and G. Vindigni, "A comparative institutional evaluation of public-private partnerships in Dutch urban land-use and revitalisation projects," Urban Stud., vol. 39, no. 10, pp. 1865-1880, 2002.

[64] I. D. Ozdogan and M. T. Birgonul, "A decision support framework for project sponsors in the planning stage of build-operate-transfer (BOT) projects," Constr. Manage. Econ., vol. 18, no. 3, pp. 343-353, 2000.

[65] A. J. Pallett, "Controlling the London underground power supply system under the power private finance initiative (PFI)," in Proc. Int. Conf. Hum. Interfaces Control Rooms, Cockpits Command Centres, Bath, U.K. Institution of Electrical Engineers, Jun. 21-23, 1999, pp. 452-457.

[66] M. Pearson, "Opportunities and Obstacles for wider adoption of PPP models in Hong Kong," in Proc. Public Private Partnerships - Oppor. Challenges, Hong Kong: Hong Kong Convention and Exhibition Centre, Feb. 22, 2005, p. 8.

[67] D. H. Peters and T. Phillips, "Mectizan donation program: Evaluation of a public-private partnership," Trop. Med. Int. Health, vol. 9, no. 4, pp. A4-A1, 2004

[68] R. R. Powell, Basic Research Methods for Librarians, 2nd ed. Norwood, NJ: Ablex, 1991.

[69] L. Qiao, S. Q. Wang, R. L. K. Tiong, and T. S. Chan, "Framework for critical success factors of BOT projects in China," J. Proj. Finance, vol. 7, no. 1, pp. 53-61, 2001.

[70] M. Replogle. (2008). Environmental Defense Communications. [Online]. Available: http://environmentaldefense.org/go/transportation

[71] M. Rogers, Engineering Project Appraisal: The Evaluation of Alternative Development Schemes. Oxford, U.K.: Blackwell, 2001.

[72] M. B. Sarker, P. S. Aulakh, and S. T. Cavusgil, "The strategic role of relational bonding in interorganizational collaborations: An empirical study of the global construction industry," J. Int. Manage., vol. 4, no. 2, pp. 415421,1998

[73] W. H. Shaw, "Engineering management in our modern age," in Proc. IEEE Int. Eng. Manage. Conf., Cambridge, U.K.: IEEE Press, Aug. 18-20, 2002, vol. 2, pp. 504-509.

[74] J. H. Steiger and J. C. Lind, "Statistically based tests for the number of factors," presented at the Annu. Meet. Psychometric Soc., Iowa City, IA, 1980.

[75] J. P. Stevens, Applied Multivariate Statistics for the Social Sciences, 3rd ed. Mahwah, NJ: Erlbaum, 1996.

[76] C. M. Tam, "Build-operate-transfer model for infrastructure developments in Asia: Reasons for successes and failures," Int. J. Proj. Manage., vol. 17, no. 6, pp. 377-382, 1999

[77] K. Tanczos and G. S. Kong, "A review of appraisal methodologies of feasibility studies done by public private partnership in road project development," Periodica Polytechnica ser. Trans. Eng., vol. 30, no. 1, pp. 71-81, 2002.

[78] R. L. K. Tiong, "CSFs in competitive tendering and negotiation model for BOT projects," ASCE J. Constr., Eng. Manage., vol. 122, no. 3, pp. 205$211,1996$.

[79] S. Q. Wang and L. K. Tiong, "Case study of government initiatives for PRC's BOT power plant project," Int. J. Proj. Manage., vol. 18, no. 1, pp. $67-78,2000$.

[80] J. Warchus, "Government IT procurement guidelines: The treasury taskforce guidelines for IT PFI - A recipe for successful IT projects?" Comput. Law Secur. Rep., vol. 17, no. 3, pp. 189-191, 2001.

[81] P. D. C. Wijayatrunga, "Economic/financial impact of BOO/BOT projects in electricity generation sector: A case study," in Proc. 34th Univ. Power Eng. Conf. (UPEC), Leicester, U.K.: Technological Educational Institute, Sep. 14-16, 1999, pp. 656-659.

[82] W. Wojtkowski and D. Walker, "Natural gas industry: The effects of public-private partnership on e-commerce standards in the commodity market," Failure Lessons Learned Inf. Tech. Manage., vol. 3, no. 3, pp. 111-119, 1999.

[83] P. S. P. Wong and S. O. Cheung, "Structural equation model of trust and partnering success," ASCE J. Constr. Eng. Manage., vol. 128, no. 1, pp. 70-80, 2005.

[84] World Bank, "Bidding for private concessions-the use of world bank guarantees," World Bank Project Finance and Guarantees Dept., Washington, D.C., RMC Discuss. Paper Ser. 120, 1998.

[85] S. Ye and R. L. K. Tiong, "NPV-at-risk method in infrastructure project investment evaluation," ASCE J. Constr., Eng. Manage., vol. 126, no. 3, pp. 227-233, 2000

[86] X. Zhang, "Concessionaire selection: Methods and criteria," ASCE J. Constr., Eng. Manage, vol. 130, no. 2, pp. 235-244, 2004

[87] X. Q. Zhang, "Paving the way for public-private partnerships in infrastructure development," ASCE J. Constr., Eng. Manage, vol. 130, no. 1, pp. 71-80, 2005.

[88] W. R. Zhang, S. Q. Wang, R. L. K. Tiong, S. K. Ting, and D. Ashley, "Risk management of Shanghai's privately financed Yan'an Donglu Tunnels," Eng. Constr. Arch. Manage., vol. 5, no. 4, pp. 399-409, 1998.

[89] B. Zhu, C. C. Li, W. Jin, and H. Y. Lv, "Research on the government management pattern of the Chinese electric power build-operate-transfer project application," in Proc. 13th Int. Conf. Manage. Sci. Eng., Lille, France: IEEE, Oct. 5-7, 2006, pp. 1930-1933.

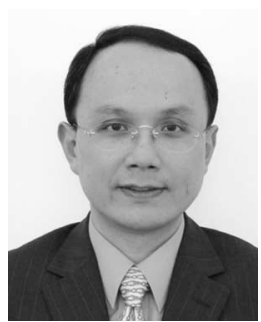

S. Thomas Ng received the Ph.D. degree from the University of Manchester Institute of Science and Technology (UMIST), Manchester, England.

$\mathrm{He}$ is an Associate Professor with the Department of Civil Engineering, The University of Hong Kong, Hong Kong. He was engaged with the construction industry for more than ten years and participated in a number of construction projects. His current research interests include construction procurement, contractor and consultant selection, delays mitigation, time/cost relationship, and construction

information technology.

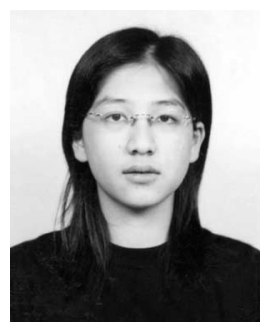

eed journals.
Yoki M. W. Wong received the B.Eng. degree in civil engineering and the M.Phil. degree from The University of Hong Kong, Hong Kong.

She is currently with the Department of Civil Engineering, The University of Hong Kong. Her research interests include public private partnerships, in particular on how to assess the performance of consortium at the operation stage as well as the conflicting interests between various stakeholders in public-private partnership (PPP) projects. She is author or coauthor of several publications in leading international refer-

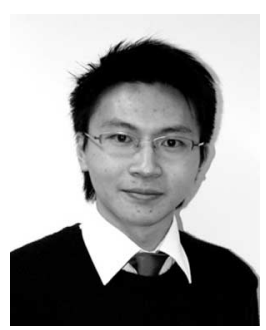

James M. W. Wong received the B.S. degree in building technology and management and the Ph.D. degree in construction economics from Hong Kong Polytechnic University, Hung Hom, Hong Kong.

$\mathrm{He}$ is currently a Postdoctoral Research Fellow with the Department of Civil Engineering, The University of Hong Kong, Hong Kong, involving in diversified construction-related research and consultancy projects, including construction economics and forecasting, construction procurement, project management, professional development, sustainability in construction, and business failure in construction. 